\title{
STRUCTURAL AND MICROVASCULAR STUDY OF SOLEOUS MUSCLE OF WISTAR RATS AFTER SECTION OF THE SCIATIC NERVE
}

\author{
Ana Cristina Camillo, Rodrigo de Carvalho Rocha, Renato Paulo Chopard
}

\begin{abstract}
It is not well established yet the relationship between the activation of satellite cells and skeletal muscle microcirculation after surgical denervation. Trough scanning and transmission electron microscopy methods, we studied comparatively the alterations of the soleus muscle in Wistar rats after surgical denervation. Our results evidenced the activation, duplication and migration of satellite cells to the interior of muscle fibers coexisting with a raise in the capillary density characterized by a higher number of anastomosis and capillary sprouts. We conclude that the microcirculation plays a key role in the regenerative process.
\end{abstract}

KEY WORDS: soleus muscle, denervation, microcirculation, sattelite cells.

\begin{abstract}
Estudo ultraestrutural e microvascular do músculo sóleo de ratos Wistar após secção do nervo ciático

RESUMO - Ainda não está suficientemente estabelecida a relação entre a ativação das células satélites e a microcirculação muscular, após denervação cirúrgica. Através de métodos de microscopia eletrônica de transmissão e varredura, foram estudadas comparativamente as alterações do músculo sóleo, de ratos Wistar, após sua denervação.Os resultados evidenciaram que no músculo denervado ocorre ativação, duplicação e migração das células satélites para o interior da fibra muscular, acompanhadas de aumento de densidade da rede capilar, caracterizada por maior número de anastomoses e brotamentos angiogênicos. Fica assim evidenciada a importância da microvascularização nos processos biológicos de reparação muscular.
\end{abstract}

PALAVRAS-CHAVE: músculo sóleo, denervação, microvascularização, células satélites.

The structural complexity of skeletal muscle is related to its functional capacity; therefore we may assume that in several pathologic conditions such as immobilization or nerve damage, changes in the morphophysiology are a natural response. After lesion, atrophy, death and disappearing of a muscle cell constitute regular responses dependent on several factors like etiology of the lesion and time of exposition. The regeneration of skeletal muscle is ruled by extrinsic factors, which are associated with reinervation and stromal signals ${ }^{1}$. Le Gros Clark ${ }^{2}$ clearly disagrees, stating that intrinsic factors are fundamental for appropriate healing. Whether intrinsic or extrinsic factors may be, tecidual lesion leads to inflammation with reduced muscular activity in order to allow proper reconstruction of cellular environment where satellite cells play a key role $\mathrm{e}^{3,4,5}$.
There are three leading causes of activation of satellite cells: muscle hypertrophy, immobilization and muscular regeneration. According to Baranska et al. ${ }^{6}$, satellite cells serve as myonuclei pools for muscular development functioning as "guides" or "memories" for structural organization. In periods of intense development, satellite cells increase in number and appear to show striking morphological adaptations such as increased Golgi apparatus and endoplasmic reticulum ${ }^{7}$. During immobilization followed by atrophy with increasing levels of loss of muscle power, after four weeks, satellite cells start to respond because of the augmented levels of myogenic factors triggered by loss of contractility according to Kauhanen and Boguslawsky.

The functional action of satellite cells was studied in detail by Baranska et al. ${ }^{6}$ and Bonavaud et al. ${ }^{9}$. The relationship between denervation and

Department of Anatomy, Biomedical Sciences Institute, University of São Paulo (USP), São Paulo SP, Brazil.

Received 2 December 2003, received in final form 5 March 2004. Accepted 3 May 2004.

Dr. Renato Paulo Chopard - Department of Anatomy, Biomedical Sciences Institute, University of São Paulo - Avenida Lineu Prestes 2415 - 05508-900 São Paulo SP - Brasil. E-mail: rchopard@usp.br 
satellite cells activity was studied by Winchester and Gonyea ${ }^{10}$, Snow ${ }^{11}$ and Pena et al. ${ }^{12}$. The period of major regeneration capability after a denervation event occurs in the first four months; satellite cells proliferate, migrate and start the healing process of damaged muscle ${ }^{13}$. Until the first six months, these cells maintain their metabolism; it appears that in order to keep the same metabolic level, neural stimulation needs to be present. With approximately two years, skeletal muscle fibres start an irreversible degeneration process, and reinervation is not accompanied by functional status recover ${ }^{14}$.

Trauma in skeletal muscle is accompanied by a transitional dilatation of blood vessels through changes in the capillary network and a concomitant local inflammatory process followed by tecidual ischemia during two weeks ${ }^{15}$. Postural muscles in which type II fibres predominate, as soleus muscle, present a capillary density two times bigger than phasic muscles ${ }^{16}$. We may conclude that since satellite cells are neurodependent cell types, their function and activation are also vascular dependent. In order to change from its resting state to its proliferative one, these cells heavily depend on its blood supply ${ }^{15}$. The new morphological arrangement of blood vessels will work as a facillitatory structure for proper activation, proliferation and migration of satellite cells ${ }^{17}$.

This study had as aim analyzed the ultrastructural and microvascular aspects of soleous muscle after section of the sciatic nerve.

\section{METHOD}

Fifteen Wistar rats of both sexes weighting 250 to 320 grams were utilized. In each animal, two surgical steps were realized. In the first surgical procedure, the animals were anestheziated with atropine $0.05 \mathrm{mg} / \mathrm{Kg}$ intraperitonial and after ten minutes et was perfomed the administration of kuetamine $25 \mathrm{mg} / \mathrm{Kg}$ intraperitonially associated to the xylazine $10 \mathrm{mg} / \mathrm{Kg}$. The sciatic nerve was sectioned through an incision in the posterolateral aspect of the thigh. The incision had its origin in the border of the iliac crest until the medial third of the thigh. The musculature was detached following the exposition of the nerve and its demarcation in two different points $0.5 \mathrm{~cm}$ distant from each other. The nerve was cut, the segment extracted and all the anatomical planes were reconstructed surgically. The animals were kept under observation for 3-4 months until reoperation. In the second surgical procedure, the animals were sacrified with thiopental $(40 \% \mathrm{mg} / \mathrm{Kg})$. It was accomplished an extraction of a transversal segment of the soleus muscle for analysis under scanning and transmission electron microscopy. The contralateral hind limb (non denervated) was used, in each animal, as a control.
Transmission electron microscopy - For this method, 10 animals weighting 280 to 310 grams were utilized. Animals were killed, and the transversal segment of the soleus muscle was divided in three parts: proximal, medium and distal. Samples were dehydrated in graded alcohols from $60 \%$ to $100 \%$ following two immersions in propylene oxide for 20 minutes each for polymerization. Blocks were cut in an ultramicrotome LEICA for ultrathin sections. Samples were analyzed under an electron transmission microscope JEOL 10010.

Scanning electron microscopy - For this method, 5 animals were utilized with similar weights of the last procedure. The contralateral hind limb was used as a control for the analysis of the microcirculation. The animals were killed and perfused with saline solution, followed by the cannulation of the abdominal aorta distal to the renal arteries. After clearing vessels from blood, methyl-metacrilate (Mercox") was perfused in order to get vascular casts. Two hours were left for proper polymerization. Hind limbs were extracted and immersed in hot water for additional two hours. Each sample was treated according to Ohtani ${ }^{18}$ for maceration of biological material, immersion in $\mathrm{NaOH} 10 \%$. Finally, samples were mounted for observation under a scanning electron microscope.

\section{RESULTS}

We could observe the structure of the satellite cells in resting state in the control samples, and its proliferative and migratory activity in samples of denervated muscle. No differences between the parts, proximal, medium and distal, could be noted. During the cellular activation process, significant nuclei elongation and increase in the number of membrane process can be observed, suggesting migratory activity. Activated satellite cells direct their processes to muscle fibres where different nuclei morphology can be observed (Fig 1). Proliferation leads to changes in the nuclei that diffuse into the muscle fibre in degeneration in order to start the healing process.

Under scanning electron microscopy, we could observe the following differences between both groups: the denervated soleus muscle presents a well-determined dense capillary network of sinuous loops. These loops branch freely until forming bridges of two or more. Bigger loops follow a more compact pattern whereas smaller present regular spaces and less compactation. Blood vessels in the soleus muscle parenchyma show a longitudinal orientation with anastomotic bridges between them (Fig 2). Tortuous loops, branches and anastomotic bridges of capillaries can be localized encir- 


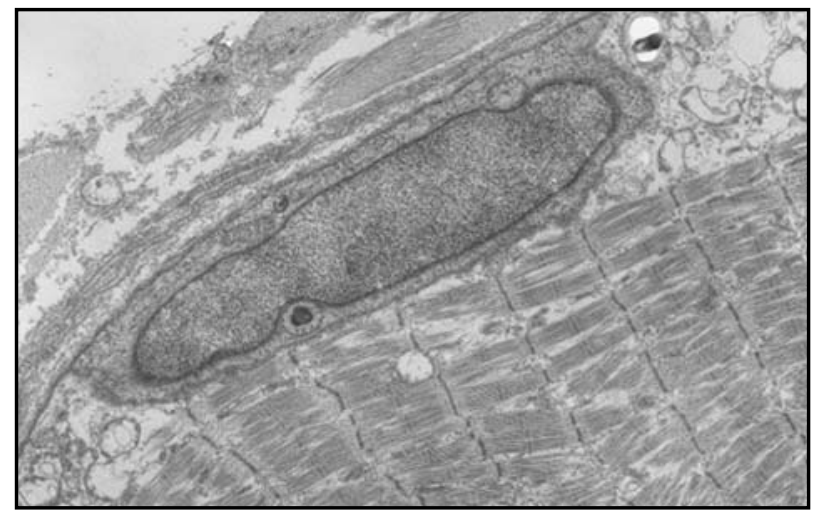

Fig 1. Photomicrograph of a transmission electron microscopy of the innervated soleus muscle. Observe the satellite cell together with the myofibrils of the striated muscle cell. 6000x.

cling a capillary of greater diameter (Fig 3). These smaller capillaries also present closed loops and sprouts. The space between both structures diminishes as they progress closer to each other, but a closed network is not established. The distance between blood vessels is preserved. In the innervated soleus muscle, the number of anastomotic bridges decreases, but circular loops of communication are still present. Under healthy conditions, the parallelism of blood vessels is striking, vessels of great and medium caliber predominating. Higher magnifying reveals spiraled capillaries with well-preserved distances between them but with a lower incidence of latero-lateral bridges among them, when compared with denervated conditions.

\section{DISCUSSION}

According to Schultz and McCormick ${ }^{7}$, satellite cells originate from sommits and appear as a diffe-

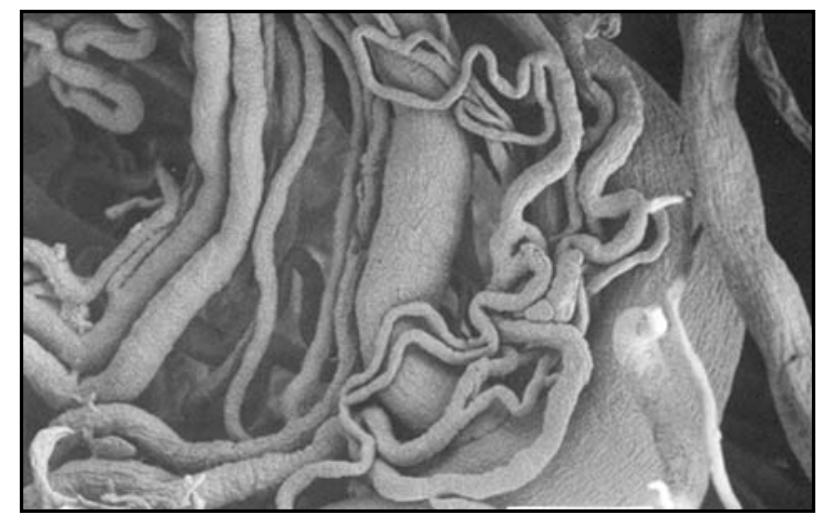

Fig 2. Photomicrograph of a scanning electron microscopy of the innervated soleus muscle. Observe longitudinal orientation of blood vessels with anastomotics bridges between them. 380x. rent embryonary myoblast cell type, in great number, and add to new nuclei of the muscular tissue in development. The satellite cell corresponds to the memory of muscle fibres, with high resistance rates in the post-denervated lesioned tecidual medium. During the process of cellular activation, we could observe an increase in the number of some cellular organelles, especially mitochondria that interfere in the biophysical process of energy production, increasing it. At this point, leaving the resting state, the satellite cell doubles its mitogenic capacity and augments the number of membrane processes starting the motility phenomenon.

In fact, Wells ${ }^{19}$ believes that cellular motility is a neurochemical and biophysical event that induces and promotes a migratory action of the satellite cell. It becomes clear that in the presence of muscle failure, as it is found in denervated muscles, satellite cells start a complex biological process in order to guarantee proper tecidual regeneration. In the majority of cases, skeletal muscle presents a vascular architecture with parallel or oblique design. According to the description of blood supply classification of skeletal muscle ${ }^{17}$, we have classified soleus muscle as class III, because of the presence of a central major artery, external sural artery, and of a diffuse collateral network that extends through the muscle belly. The tri-dimensional arrangement of blood vessels guarantees the homogeneity of the vascular supply which can be related to the activation process of satellite cells, and is non dependent on the muscle segment: proximal, medium, distal. Hudlika ${ }^{20}$ reports that the microcirculation of skeletal muscle is a dynamic system that changes its size and shape depending on the specific pathological process. In the healthy muscle

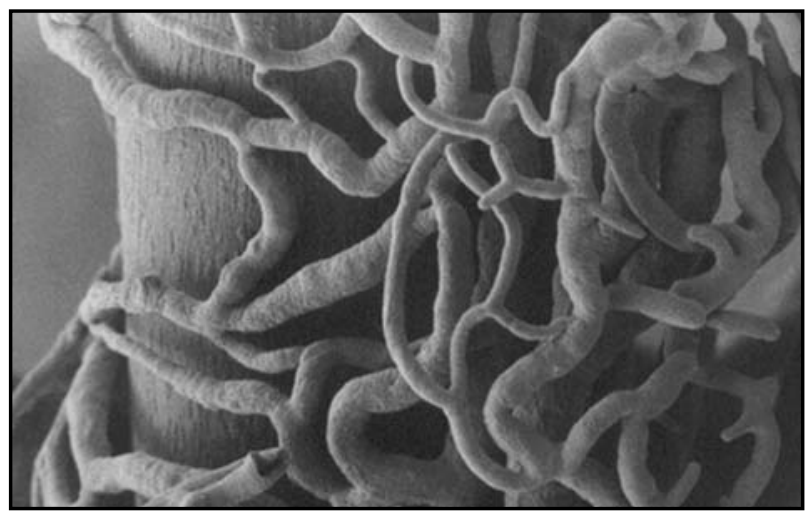

Fig 3. Photomicrograph of a scanning electron microscopy of the denervated soleus muscle. Observe tortuous loops of capillaries encircling a vessel of greater diameter. 460x. 
we have observed a more simple vascular architecture with blood vessels running parallel to each other and a considerable high number of anastomotic bridges between capillaries. On the other hand, the presence of denervation have altered the angioarchitecture by increasing the capillary density, by changing its morphology in order to also increase the contact area, the number of anastomotic bridges and the development of sprouts to further establish new blood vessels. We believe that these changes are promoted by a series of cellular events including the activation satellite cells.

In conclusions denervation causes muscle atrophy generating morphological changes non-dependent on the considered muscular segment: proximal, medium or distal. This process leads to activation of satellite cells leading to changes in its shape, internal organization and localization. Following denervation, capillaries adopted a tortuous shape, increased in number and sprouts have developed also increasing the number of anastomotic bridges. Blood vessels of bigger caliber maintained their morphological features.

\section{REFERENCES}

1. Murray MA, Robbins N. Cell proliferation in denervated muscle identify and origin of dividing cells. Neuroscienses 1982;7:1823-1833.

2. Le Gros Clarck. Skeletal muscle tissue in culture: the structure and function of muscle. Atlanta: Academic Press, 1960:314

3. Mauro A. Satellite cell of skeletal muscle fibers. J Biophys Biochem Cytol 1961;9:493-498.
4. Moss FP, Le Blond CP. Satellite cells the source of nuclei in muscles of growing rats. Anat Rec 1971;170:421-435.

5. Alberts B, Johnson A, Lewis J, Raff M, Roberts K, Walter P. Biologia molecular da célula. 3.Ed. Porto Alegre: Artes Médicas; 1997;1178.

6. Baranska, W, Baran, W, Skopinski, P, Ziembra, H. Quantitative and ultrastructural evaluation of satellite cells in soleus muscle from rats kept in hypokinesia. Exp Mol Pathol 1997;64:13-21.

7. Schultz E, McCormick KM. Skeletal muscle satellite cells. Rev Physicol Biochem Pharmacol 1994;123:213-257.

8. Kauhanen S, Boguslawsky K. Satellite cell proliferation in rabbit hindlimb muscle following immobilization and reimobilization: an imunohistochemical study using M1B1 antibody. Acta Neuropathol 1998;95:165-170.

9. Bonavaud S, Thibe RTP, Gherardi RK, Barlovatzmeimon G. Primary human muscle satellite cell culture variations as cells field, proliferation and differentiation rates according to age and sex of donors, site of muscle biopy, and delay before proceding. Bioc Cells 1997;89:233-240.

10. Winchester PK, Gonyea WJ. Regional injury and the terminal differentiation of satellite cells in stretched avian slow tonic muscle. Dev Biol 1992;151:459-472.

11. Snow MH. A quantitative ultrastructure analysis of satellite cells in denervated fast and slow muscle of the mouse. Anat Rec 1983;207:593-604.

12. Pena J, Jimena I, Luque E, Vaamonder R. New fiber formation in rat soleus muscle administration of enervated muscle extract. J Neurol Sci 1995;128:14-21.

13. Schmalbruch H, Al-Ammod, Lewis DM. Morphology of long-term denervated soleus muscle and the effect of chronic electrical stimulation. J Physiol 1991;441:233-241.

14. Rames MJ, Azze RJ, Camillo AC. Reabilitações de nervos periféricos no membro superior. In Medicina de reabilitação aplicada á ortopedia e traumatologia Roca, São Paulo; 1999:225-250.

15. Lewis DH, Lim R C. Studies on the circulatory pathophysiology of trauma. Acta Orthop Scand 1970;41:17-36.

16. Folkow B, Halicka H. A comparison between read and white muscle with respect to blood supply, capillary surface area and oxygen uptake during rest and exercise. Microvasc Res 1968;1:1-14.

17. Myrhage R, Eriksson E. Arrangement of the vascular bed in different types of skeletal muscles. Prog Appl Microcirc 1984;5:1-14.

18. Ohtani $\mathrm{O}$. Three-dimensional organization of the connective tissue of the human pancreas: a scanning electron microscopic study of the NAOH treated tissues. Arch Histol Jpn 1987;50:557-566.

19. Wells A. Introduction to cell motility. Microsc Res Tech 1998;43:357-368.

20. Hudlika O. Growth of capillaries in skeletal and cardiac muscle. Circ Res 1982;50:451-460. 